\title{
Teachers in Rural Area of Java Utilize Free Digital Platforms During COVID-19 Pandemic
}

\author{
Ema Aprilisa ${ }^{1, *}$ Badrun Kartowagiran ${ }^{2}$
}

\author{
${ }^{I}$ Department of Biology Education, Faculty of Mathematics and Science, Universitas Negeri Yogyakarta, Indonesia \\ ${ }^{2}$ Educational Research and Evaluation Department, Graduate School, Universitas Negeri Yogyakarta, Indonesia \\ ${ }^{*}$ Corresponding author. Email: ema.aprilisa@uny.ac.id
}

\begin{abstract}
Online learning is a solution during the COVID-19 pandemic. Unfortunately, not all schools have online learning facilities. Therefore, free digital platforms are an alternative solution. This research uses a mixed-method with two steps data collection strategy. The first stage was a survey of teachers in Pacitan Regency, East Java, Indonesia, as one of the rural areas in Java. We collect more data based on participant responses by using in-depth interview techniques to explore their perspectives. WhatsApp is the most widely used platform among the participants. The second and the third platforms are Google Classroom and YouTube. They chose it based on the features that are easy to understand and access, facilitate better communication with students because it does not require optimal internet network support, and better organize learning activities. This study shows that the free digital platform, which is not intended for education, has become a favorite for teachers who teach in places with limited conditions, such as rural areas of Java. This finding can also be used as an insight for developing a Learning Management System (LMS) suitable for inadequate conditions.
\end{abstract}

Keywords: Free Digital Platforms, Online Learning, LMS, WhatsApp.

\section{INTRODUCTION}

World Health Organization (WHO) declared the COVID-19 pandemic on March 11, 2020. Based on Dr. Tedros Adhanom Ghebreyesus's as WHO Director-General opening remarks at the media briefing, the number of cases of COVID-19 outside China has increased thirteenfold, and the number of affected countries has tripled over the past two weeks. More than 118,000 cases in 114 countries and 4,291 people had lost their lives because of COVID-19. The number keeps growing, and there have been 226,844,344 confirmed cases of COVID-19 and $4,666,334$ deaths, based on the WHO Coronavirus (COVID-19) Dashboard on September 17, 2021.

COVID-19 became one of the most significant challenges in the education system. Many governments, including Indonesia, decided to stop face-to-face instructions to reduce the spread of the corona virus. Teachers have to adapt their teaching by changing their methods from offline classrooms to online. It may not affect areas with adequate internet access and a well-structured online learning management system. However, in most regions of
Indonesia, including in rural areas of Java Island, this is quite a challenge.

The implementation of distance learning systems carried out by Indonesian education in the COVID-19 pandemic situation was poor. Students feel a lot of stress due to a lack of comprehensive distance learning management [1]. Online learning is entirely new for students, teachers, and parents in Indonesia. Some fundamental problems arise.

Teachers face restrictions in the choices of teaching methods, less coverage of curriculum content, lack of technology skills for preparing and implementing online learning, lacks e-resources in the Indonesian language, so they need more time to develop the content and longer screen time for giving feedback on students' work that makes teachers overloaded and exhausted, also higher internet bill [2]. Many Indonesians still use pay-per-bit internet connections. As many as $91.8 \%$ of the students in Indonesia have internet access. But, $91.8 \%$ of the students use mobile data to access the internet, and only $8.20 \%$ have access to the cable or fiber internet connection. Only $16.8 \%$ of students have fast internet speeds, as many as $67.6 \%$ of students have sufficient 
internet access speed, $12.1 \%$ of students have slow internet speeds for distance learning, and $3.52 \%$ of Indonesian students still have to deal with prolonged internet access [3].

Even so, teachers in Indonesia are still trying to implement distance learning in order to keep the learning process going. Some of them use Google Classroom as a part of Google Apps for Education (GAFE) [4], WhatsApp Messenger [5], YouTube, email, and social media [6]. Based on such findings, we want to find out how teachers in the rural area of Java adapt to teach in the COVID-19 pandemic situation, especially about how they utilize the free digital platforms.

\section{METHODOLOGY}

This research uses a mixed-method with two steps data collection strategy. The first stage was a survey of teachers in 5 high schools, 20 junior high schools, and 50 primary schools located in Pacitan Regency, East Java, as one of the rural areas in Java. The questionnaire has been tested for content validity by experts and resulted in nine multichotomous questions to find out various aspects about teachers' use of free digital platforms. Based on the participant responses, we collected more data through an in-depth interview to explore their perspectives on utilizing the free digital platform as an educational tool during the COVID-19 pandemic.

\section{FINDINGS AND DISCUSSION}

\subsection{The Most Widely Used Free Digital Platform}

The participants revealed that some free digital platforms had been used to support the learning process during the Covid-19 pandemic. They may mention more than one platform for the first question. The survey participants responded to shows that all teachers had used WhatsApp Messenger to facilitate learning from home, starting in March 2020 when the government closed school activities due to the COVID-19 pandemic. The participants also use another free digital platform to help them teach.

As many as $55.4 \%$ of participants use Google Classroom, $45.8 \%$ use Youtube, $10.8 \%$ use e-mail, $8.4 \%$ use Instagram, 3.6\% use Telegram, and $2.4 \%$ use Facebook to support their students learning from home. WhatsApp Messenger is the most frequently used free digital platform to support the learning process during the Covid-19 pandemic. This was stated by $77.1 \%$ of the participants. Other $13.3 \%$ of participants use Telegram more often, $2.4 \%$ use Youtube, and $1.2 \%$ use Facebook more than any other free digital platform for facilitating learning from home activity during a pandemic.

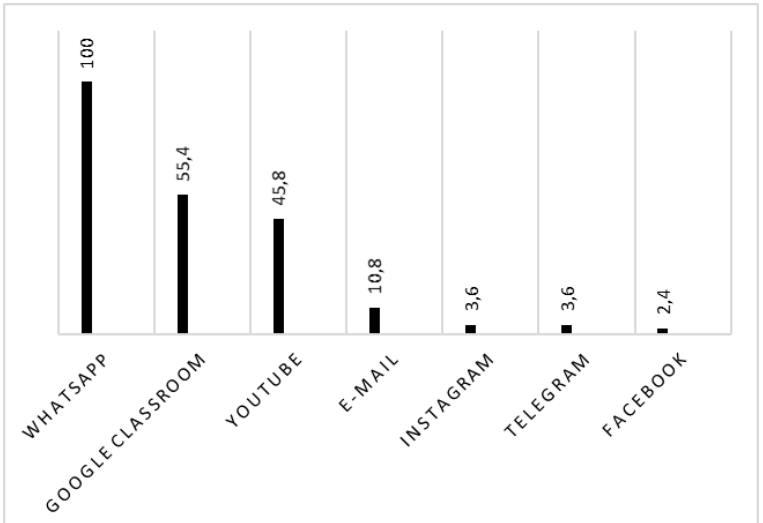

Figure 1 Percentage of participants who have used specific free digital platforms to support the learning process during the COVID-19 pandemic (each participant may answer more than one platform)

WhatsApp Messenger is an American free digital platform owned by Facebook Inc. Users only require a cellular telephone number to sign up. According to its official website, WhatsApp allows users to send messages (text, voice, image, and video) for free using an internet connection. It also provides a group chat facility to share news, photos, and videos with up to 256 people at once. It also provides the facility to send PDFs, documents, spreadsheets, slideshows, and more, up to $100 \mathrm{MB}$. The platform runs on mobile devices and is accessible from a desktop computer. These various conveniences make WhatsApp popular, even to support learning by teachers.

Meanwhile, Google Classroom, as the second most favorite free digital platform in this research to support the learning process during the COVID-19 pandemic, is a part of the online Google Apps for Education (GAFE) applications. Google Classroom provides a central site for communicating with students, sending feedback, and providing homework. The implication of Google Classroom in implementing education in Indonesia is to improve teachers' quality, and the students use technology wisely [7]. Google Classroom is recommended as a learning app for distance learning to overcome the problems of equitable distribution of infrastructure and costs for accessing the internet [3].

Youtube is in third place as a free digital platform that participants have used to facilitate learning from home activities. It is also accessed by $94 \%$ of internet users between 16-64 years old in Indonesia. Videosharing sharing platform and only needs a Google account to create an account to watch videos or create their channel. YouTube is driven by two types of users, people who have channels and upload their videos called creators and the viewers who watch videos, interact with other users and creators via the comment section, and subscribe to channels [9]. This platform with video-based content has become a teacher's choice because it is considered educational content by the material that students must learn. 


\section{2. $\quad$ Reasons why a free digital platform is chosen}

The features are the main reason why a free digital platform is chosen. Teachers said they prefer using a familiar platform or have easy-to-understand and easy-access features. Those who decided WhatsApp admitted that the application had been used frequently to communicate with students, even long before the pandemic. Therefore, when students have to learn from home, these teachers use WhatsApp to make it easier.

WhatsApp is indeed one of the most popular messaging platforms in this country. There were at least 68 million active Indonesian WhatsApp users by 2021 [10]. It is becoming a popular messenger platform because WhatsApp provides various options for its users free of charge. Another reason most people use WhatsApp is that everyone else uses it regularly. It is the power of social influence. Certain information provided by WhatsApp, such as the status of messages sent, read, or when someone last opened their WhatsApp account, is recognized as very useful and helps users communicate effectively [11].

Some teachers, as participants, also said that they choose a platform based on how it facilitates better communication with students because it does not require optimal internet network support. For example, some of the participants selected WhatsApp because it does not need optimal internet network support so that students in poor internet connection areas can participate in distance learning. WhatsApp is suitable to use in unstable or poor internet connection areas. Students can collaborate, and teachers can also provide instructions and materials for students by using this platform [12].

Google Classroom is considered to have full features so that teachers can give announcements, instructions, assignments, provide material in various media, and even conduct tests using this platform. Some participants said that Google Classroom could better organize learning activities. They can arrange every learning activity at the beginning of the semester and schedule sessions, materials, discussion topics, and various learning activities, including tests, to be accessible by a student at the time set on the platform.

Teachers mentioned that the Google Classroom feature made it easy for students to get lesson plans and study materials. It is also recognized as very helpful for conducting virtual learning. Some teachers use the task feature that can facilitate students to submit their assignments, automatically grade them, and provide comments on the results of student work. Google Classroom also can encourage collaborative learning because students can create groups and submit assignments or project work, then teachers can quickly assess their performance [13].
Table 1. The reason why the specific free digital platform is chosen

\begin{tabular}{|l|l|}
\hline Reason & Percentage of participants \\
\hline $\begin{array}{l}\text { The features are easy to } \\
\text { students }\end{array}$ & $63.4 \%$ \\
\hline $\begin{array}{l}\text { Facilitates better } \\
\text { communication with students } \\
\text { because it does not require } \\
\text { optimal internet network } \\
\text { support }\end{array}$ & $52.4 \%$ \\
\hline $\begin{array}{l}\text { Can be used to organize } \\
\text { learning activities better }\end{array}$ & $45.1 \%$ \\
\hline $\begin{array}{l}\text { The features are easy to } \\
\text { understand and access by } \\
\text { teachers }\end{array}$ & $36.6 \%$ \\
\hline $\begin{array}{l}\text { Has complete features to } \\
\text { support learning }\end{array}$ & $19.5 \%$ \\
\hline
\end{tabular}

*Each participant may answer more than one reason

\section{CONCLUSION}

As a participant in this study who works in the rural area of Java, teachers used WhatsApp Messenger the most, followed by Google Classroom and YouTube as a free digital platform to support learning from home activities during the COVID-19 pandemic. They chose it based on the features that are easy to understand and access, facilitate better communication with students because it does not require optimal internet network support, and better organize learning activities.

This study also shows that the free digital platform, which is not intended for education, has become a favorite for teachers who teach in places with limited conditions, such as rural areas of Java. This finding can also be used as an insight for developing a Learning Management System (LMS) suitable for inadequate conditions.

\section{REFERENCES}

[1] Churiyah, M., Sholikhan, S., Filianti, F., \& Sakdiyyah, D. A, Indonesia education readiness conducting distance learning in Covid-19 pandemic situation. International Journal of Multicultural and Multireligious Understanding, 2020, vol. 7, pp. 491-507.

[2] Putri, R. S., Purwanto, A., Pramono, R., Asbari, M., Wijayanti, L. M., \& Hyun, C. C. Impact of the COVID-19 pandemic on online home learning: An explorative study of primary schools in Indonesia, International Journal of Advanced Science and Technology, 2020 vol. 29 , pp. 4809-4818

[3] Utomo, M. N. Y., Sudayanto, M., \& Saddhono, $\mathrm{K}$. Tools and strategy for distance learning to 
respond COVID-19 pandemic in Indonesia, Ingénierie des Systèmes d'Information, 2020, vol. 25, pp. 383-390.

[4] Sudarsana, I. K., Putra, I. B. M. A., Astawa, I. N. T., \& Yogantara, I. W. L., The use of Google classroom in the learning process. Journal of Physics: Conference Series, 2019. vol. 1175, p. 012165

[5] Rinekso, A. B., \& Muslim, A. B. Synchronous online discussion: Teaching English in higher education amidst the covid-19 pandemic, JEES (Journal of English Educators Society), 2020, vol 5, pp. 155-162.

[6] Aliyyah, R. R., Rachmadtullah, R., Samsudin, A., Syaodih, E., Nurtanto, M., \& Tambunan, A. R. S. The perceptions of primary school teachers of online learning during the COVID-19 pandemic period: A case study in Indonesia, Journal of Ethnic and Cultural Studies, 2020, vol. 7, pp. 90-109.

[7] Sudarsana, I. K., Putra, I. B. M. A., Astawa, I. N. T., \& Yogantara, I. W. L., The use of Google classroom in the learning process. Journal of Physics: Conference Series, 2019, vol. 1175, p. 012165.
[8] Lidwina, Andrea. 94\% Orang Indonesia Akses YouTube dalam Satu Bulan Terakhir, 2020, retrieved from https://databoks.katadata.co.id/datapublish/2021/ 02/17/94-orang-indonesia-akses-youtube-dalamsatu-bulan-terakhir.

[9] Moreau, Elise. What Is YouTube: A Beginner's Guide, 2020, retrieved from https://www.lifewire.com/youtube-101-3481847.

[10] Iqbal, Mansoor. WhatsApp Revenue and Usage Statistics, 2021, retrieved from https://www.businessofapps.com/data/whatsappstatistics

[11] Kvashali, Irina. Why WhatsApp: The Reasons People Love Chat Apps. 2019, retrieved from https://medium.com/@amocrmglobalmarketing/ why-we-whatsapp-the-reasons-people-love-chatapps-ee08116f4300

[12] Kola, A. J., \& Sunday, O. S. Mobile-learning (M-learning) through WhatsApp messaging, Facebook, and YouTube, Nigeria, Education Journal, 2018, vol. 1, pp. 111-121.

[13] Iftakhar, S. Google classroom: what works and how, Journal of Education and Social Sciences, 2016, vol. 3, pp. 12-18. 